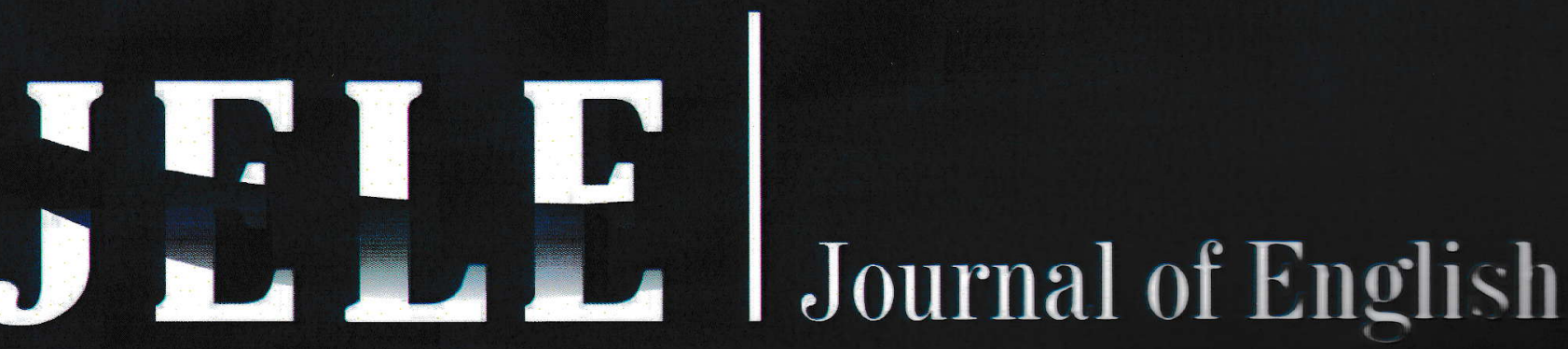 Language and Education
}

English Education Study Program Faculty of Teachers Training and Education Mercu Buana University of Yogyakarta 


\title{
VIDEO MAKING PROJECT TO IMPROVE STUDENTS' AUTONOMY AND ABILITY IN TRANSACTIONAL AND INTERPERSONAL CONVERSATIONS
}

\author{
Riko Arfiyantama \\ State Senior High School 1 Limbangan \\ Email : rikoarfiyantama@gmail.com
}

\begin{abstract}
Speaking as one of the productive skills is considered difficult for foreign language learners. One of the efforts to solve the difficulty is improving the students' autonomy in speaking practice. The study is about the use of video making to improve students' autonomy and speaking ability in transactional and interpersonal conversations. The objective of the study was to find out how video making project is implemented in classroom. Students of SMA 1 Limbangan were taken as the subject of the study. This study used classroom action research by conducting a pre-test, first cycle, and second cycle activities particularly focused on speaking. The students' speaking achievement was scored based on the video they had made. The students were also asked to fill the questionnaire to know their improvements in autonomy. The result of the research showed that the average score percentage of autonomy in pre-test was $68 \%$, cycle I result was $87 \%$ and cycle II result was $89 \%$. While the result also showed that the average of students' speaking achievements in pre-test was 60, cycle I was 68, and Cycle II was 73.It can be concluded that using Video Making project in teaching transactional and interpersonal conversations can improve the students' speaking competence as well as autonomy.
\end{abstract}

Keywords: Autonomy, Transactional, Interpersonal, Video Making, Competence

\section{INTRODUCTION}

Many studies have been conducted to investigate the effectiveness of using technology in English classroom. As the correlation, the English learning with technology actually not only improve the students' English competence but also influence the students' skills in technology. This technology use can also be used as an effective media for both inside and outside classroom which can improve the students' autonomy, motivation, satisfaction, and self-confidence in their English language learning (Fotos \& Browne, 2004: York, 2011). Then how to maximize the use of the two aspects are turning to be an interesting topic since teachers should have more new strategies in their classroom 
activities as stated in the Education Ministry Regulation.

As the consequence of the Indonesian educational system, the student-centered approach is preferable to the teacher-centered approach since the student-centered has been proven better that it can provide the students with a better learning style. In response to that, teachers should set their learning strategy in such away so the students can develop their autonomy in order to make a successful learning (Adamson and Sert, 2012). In line with that, Wlodkowski (2008: 3) also proposes some factors influencing a successful learning. They are learner's capability, the quality of the teacher, and students' personal motivation.

By comparing Adamson's suggestion and Wlodkowski's idea, there is a similarity in those different terminologies, Adamson with autonomy and Wlodkowski with motivation. Since this study focused on autonomy, it was necessary to differentiate between autonomy and motivation. Tatarko (2010: 88) explains that there are some parallels between motivation and autonomous learning. In this case, she says that motivation is actually as a result of autonomous learning. So they are inseparable. If a teacher is willing to improve the students' motivation, he should improve the students' autonomy first. In other words, autonomous learning contributes to students' enhanced level of motivation.

In 2012, Kompas.com clarified that Indonesia has been positioned in the third rank as a country with most Facebook users. It indicates that Indonesia actually has a great potential in the use of technology. It also happens in Senior High School 1 Limbangan where its students like using Facebook and surfing the internet because the school has provided sufficient internet access i.e. hotspot and computer laboratory. However, the problem is whether the technology used has been put in the correct way or not so the students can develop it as a real tool in learning and actualizing themselves. Based on preliminary observation, Senior High School 1 Limbangan students belong to passive users. They used internet only for downloading and searching materials while many of them could not upload video on YouTube or even 
made a blog. Responding to that issue, teacher should be able to benefit such students' interest and solve the students' limitation by integrating technology with the English language learning. Therefore, it is expected that they can learn English more autonomously by the assistance of technology not only during the school time but also after school. Based on the above explanation, Video Making project is proposed to be an alternative way to improve the students' autonomy in English learning. Moreover, the video making project as one of technology uses in language classroom requires the students to deal with oral communication or speaking. Therefore it is expected that the students' speaking can also be improved through such activities.

Based on the above reasons, Video Making is preferred as an alternative way to improve the students' autonomy. In the process of video making, the students are asked to perform transactional and interpersonal conversations into a video and then upload it on YouTube. The three tools they need are cell phone (to record the video), computer, and internet access. By using the project, the students are supposed to be able to learn English not only at school but also elsewhere so they can be more autonomous in learning English. At last, this study aimed at finding the effectiveness of Video Making in helping the students to improve their autonomy and ability in transactional and interpersonal conversations. To formulate the finding, Classroom Action Research (CAR) was employed in this study.

Related to the background above, the researcher formulated the research problem as follows:

1. What are the problems faced by the teacher and students of SMA 1 Limbangan in implementing Video Making project?

2. How is Video Making project implemented to improve students' autonomyand ability in transactional and interpersonal conversations?

3. What are the contributions of Video Making project to improve the students' autonomy and ability in transactional and interpersonal conversations? 


\section{Video Making}

Video Making is actually almost similar to iVideos (short, twominute, digital videos designed to evoke powerful experiences about educative ideas), iMovie, or Video Production in the language class. The first two terms (iVideos and iMovie) are the integration of video production or video making and the use of internet as the sharing media. The followings will explain how Video Making is implemented in the classroom activity.

Sentlowits (2009) states that making a video is telling a story. "It is a process that is thought out and planned far before the camera is turned on". While Masats\& Costa (2009:6) divides the video production into three levels. They are beginners, intermediate, and advanced. In the beginner level, the students are required to create a photo story with PowerPoint (images and text). While the intermediate requires the students to create a photo story with free photo story software such as Photo Story (images, text and sound). In the advanced point of view, the students are asked to create a short drama story with optional titles, subtitles and soundtrack. Wachob (2011) added that video production is easy and practical. The low cost of camera and the technology support nowadays has made the video production is easy to do. Even the use of cell phone also has an ability to record a video.

In video production, many steps should be done in order to make a successful video. Masats\& Costa (2009) suggest the following ways:

The first is the technologies to record videos. There are many tools which can be used easily by the students to record videos i.e. mobile phones, organizers, still cameras and computers with built in cameras. The choosing of the tools to record can be determined by considering the following things. The first is the practicality of the tools for example using tool that the student have such as digital camera or mobile phone. The second is the quality of the video. The use handy camera may become the best choice in this way. However, teachers should note the students to consider the combination of the two aspects and do not neglect one of the two.

When recording, the students need to make sure that the video can 
be transferred to the computer. They are asked to check whether their tools to record videos can be copied into the computer or not. There are two basic procedures in transferring the video from the tool to the computer. The first is by using "fire wire" (also called IEEE 1394 or iLink) cable if the camera does not use the memory card. The second is by using memory card. The use of memory card is the common way these days since many tools are using it. The additional procedure is by using "Bluetooth" if it uses the video function of a mobile phone.

To import the video to be a final video clip, the students need to use Editing software. Firstly, the students are asked to save all the video clips which have been recorded. Then, they are required importing their video in the editing software formats. Normally, the easy free software available online is Windows Movie Maker. However, only windows XP which has it already installed, for windows 7 and 8 , there should be downloading and installing the software first. Therefore, teachers should guide the students to have the software ready. To make easier, teachers can provide a computer laboratory for the students to edit the videos with no more than three students work on one computer at a time. For video projects, the students need to have an account to video platform (YouTube, Vimeo, etc.), internet access, and a video projector to show the results.

In video making, the students are asked to make the video by themselves. During the process, the complex tasks will involve students in design, problem-solving, decisionmaking, and investigative activities. All the students do in video making is a part of project based learning (PBL). Therefore, project based learning should be discussed to make the video making successful in its implementation. (Mergendoller\& Thomas: 2000).

\section{Transactional and Interpersonal Conversations}

In Senior High and Junior high schools, students are necessary to learn transactional and interpersonal conversations.In this case, the students are required to be able to express meanings in the transactional conversation (to get things done) and 
interpersonal conversation (to socialize).

Transactional conversation is message-oriented. Richards (1990: 54) explains that "Transactional uses of language are those in which language is being used primarily for communicating information.”

Accurate and coherent communication of the message, confirmation that it has been understood, explicitness and directness of meaning are essential. Transactional conversations are interactions which have an outcome, for example, buying something in a shop, enrolling in a school. In such contexts the range of language used is relatively limited and therefore reasonably predictable because speaking happens in real time and is often characterized by unfinished utterances, reformulation, overlapping utterances, grammatically incorrect utterances. Participants must follow cultural conventions which include factors such as gesture, body language and facial expression. Decisions have to be made about the direction of the exchange and how to deal with unexpected difficulties. Speech events differ from each other according to characteristics such as the degree of distance, formality, spontaneity and reciprocity. For example, a job interview would be characterized by distance, formality, some reciprocity and relatively little spontaneity. At the other extreme, meeting someone informally for the first time is reciprocal and spontaneous. However, even those events which seem spontaneous can in fact be predictably organized and do incorporate set phrases. So, greetings, introductions and conclusions follow predictable lines. Students at this level need be made 45 aware of conventions of transactional exchanges and introduced to the particular language which they might expect to hear and use.

Interpersonal conversation aimed at establishing or maintaining social relationships, such as personal interviews or casual conversation role plays (Eggins and Slade, 1997). The interpersonal conversation is usually used to express: (a) Greeting and leave-taking,

Making introductions, identifying oneself, (c) Extending, accepting and declining invitations and offers, (d) Making and breaking engagement,(e) Expressing and acknowledging gratitude, (f) 
Complimenting and congratulating (g) Reacting to the interlocutor's speech, (h) Showing attention, interest, surprise, sympathy, happiness, disbelief, disappointment (CelceMurcia et al., 1995).

This conversation can be done to fulfill the social interaction to the society like in socialization. The topic is free and people just produce the talk to involve in the community. In this conversation, there is also an important term that is 'dialogue'. It is defined as conversation which is written for a book, play, or film. In teaching and learning process, the dialogue is usually used by the students to perform the conversations.

\section{Autonomy}

The development of autonomous learning is gradually becoming a crucial part of many language courses. Its achievement depends on teachers who need to be able to create an environment in which students feel autonomy; hence they have a chance of becoming independent. There are many scientists in the field of foreign language competence development who agree with the positive effects of autonomous learning (Hurd et al in Tatarko, 2011: 85). In addition, Harmer (1998: 88) also states that good speaking activities can and should be motivating. If the activities are running properly and can give them sympathetic and useful feedback, the students will get tremendous satisfaction from it. After they are satisfied in learning and enjoyable, they can be independent in learning. Thus, the overall success of language learning depends on the ability of students to be autonomous since it is not sufficient for them to study only in the school time. They should study in the school time as well as after school time.

The concept of autonomy was introduced by Henri Holec in 1981 when he wrote Autonomy and Foreign Language Learning. He began by defining students' autonomy as the “ability to take charge of one's own learning", nothing that this ability "is not inborn but must be acquired either by 'natural' means or (as most often happens) by formal learning. In other words, "autonomy" is the ability which can be improved because the term 'autonomy' is ranging of high and low. 
The other theorists and researchers have many different ways of defining what autonomy is. Little (1991) argues that Autonomous learner is one who is able to take charge his own learning when he has taken full responsibility for the learning process. The idea is that one will be successful in learning crucially on himself rather on other people.

Based on the explanations above, it can be concluded that autonomy is a self-initiated motivation that pushes the student to learn, to discover, and develop what they need individually as a social creature. In other words, they have a good willingness in learning so that they can actualize themselves to be long-life learners.

\section{METHODS}

In this research, I applied qualitative approach to identify the use of video making in improving students' autonomy and ability in transactional and interpersonal conversations. In completing this research, I collected data and information from the main source, namely field research. This term referred to my efforts in obtaining the empirical data from the subject of the research. I also conducted the activity of gathering information from library facilities such as references and books which supported the efforts in conducting this research. I decided to carry out an action research in SMA N 1 Limbangan as I had been teaching there and wanted to know how is the effectiveness of using video making if it is implemented in my teaching and learning process.

The research design of this study was Action Research. It took two cycles. Cycle I consisted of four meetings and Cycle II consisted of three meetings excluded the pre and post-test. Each cycle had four steps; they were planning, acting, observing, and reflecting. The place of this research was at a state school. It was SMA N 1 Limbangan at JalanLimbangan-Boja No. 1, Limbangan, Kendal. The research was conducted in the first and second semester of the academic year of $2013 / 2014$. The pre-cycle test was conducted on November $7^{\text {th }} 2014$. The firstcycle was conducted onNovember $21^{\text {st }}-$ December $2^{\text {nd }} 2013$. Second cycle was conducted in January $20^{\text {th }}-$ February $10^{\text {th }}, 2014$. 
The study of action research involved a group of students as the subject of investigation.This action research was done at SMA $\mathrm{N} 1$ Limbangan. I conducted this action research in class XII IPA2. There were 5 males and 18 females.

Int his action research, some instruments were used in the forms of observation sheet, outsider observer, field notes, speaking rubric, students' observation sheet, questionnaire and interview. Observation sheet was used to describe the exact situation during the research was conducted. It was used by the outsider observer. He filled the observation sheet while doing the observation. The data analysis in this study consisted of observation sheet, students' questionnaires in autonomy, field note, and the students' video.

\section{FINDINGS AND DISCUSSION}

Before doing the research, the preliminary research was conducted before the research was done. I observed the students while I was teaching them. I had taught them for about four months. I had also taught some of them when they were in Tenth
Grade. According to my teaching experience, I could identify the problems faced by the students in learning English.

The lack of time to practise English made the students could not perform their best especially in oral communication. It happened because the time given by the school was only 180 minutes for each week. It was resulted when they had time to perform their speaking ability in the speaking test or practise it in the classroom context. Their problems were (1) pronouncing some English words, (2) the way how to construct a dialogue or sentence, and (4) how to make a smooth conversation or speaking. I also found that most of the students were more exposed in learning reading material from their text-book or classroom activities. They got little exposure in speaking materials because they seldom used English in the real communication.

Those problems stated above made the students' ability in speaking skill was unsatisfying and they needed a new way of learning strategy to make them more independent in learning. Therefore I concerned with the problems dealing with lack of 
autonomy and speaking skills of the students. The following paragraphs are the discussion about those two problems.

The pre-test was conducted in order to know the students' achievement in transactional and interpersonal conversation. The students were asked to make a dialogue about complaining expressions. In this activity, they required to perform a dialogue in front of the others with the given topic. The topic used was complaining the situation in the school library. One student performed as the librarian and another as the borrower of a book. The results of the students' speaking results were analyzed based on the speaking rubric.

After administering the pretest, the result was analyzed to get the students' score. The result of this pretest analysis would underline the process of planning for the first cycle. The result of the pretest was attached in the following table(appendix 13). The following table was the summary of the pre-test result.

Table 1. The Summary of Pre-test Result

\begin{tabular}{ccc}
\hline Category & $\begin{array}{c}\text { Average points earned } \\
(\mathbf{1 - 1 2})\end{array}$ & Percentage \\
\hline Pronunciation & 6.28 & $52 \%$ \\
Fluency & 7.13 & $59 \%$ \\
Comprehensibility & 7.46 & $62 \%$ \\
Vocabulary & 7.43 & $62 \%$ \\
Performance & 7.96 & $66 \%$ \\
Total / Average & 36.26 & 60 \\
\hline
\end{tabular}

The grading guide to give detail information was provided below:

Table 2. The Grading Guide to Score the Students

\begin{tabular}{ccl}
\hline $\begin{array}{c}\text { Total } \\
\text { points }\end{array}$ & Score & \multicolumn{1}{c}{ Grade } \\
\hline $50-60$ & $83-100$ & $\begin{array}{l}\text { A }- \text { exceeds } \\
\text { expectations }\end{array}$ \\
& & B - Excellent \\
$35-49$ & $58-82$ & C - Good \\
$20-34$ & $30-57$ & D - Not Yet \\
$5-19$ & $8-29$ & \\
\hline
\end{tabular}

According to the result, the average of the students' learning achievement was 60 . It showed that the students were in the grade B or excellent enough. However, the students' pronunciation and fluency should be still concerned because they got the lower score than others. The score of the students showed that there 
was no student got grade $\mathrm{A}$, and students who achieved B were 59\% (13 students) while who got $\mathrm{C}$ were $41 \%$ (9 students). Based on each category, the result showed that the average score of pronunciation was 6.28, fluency was 7.13, comprehensibility was 7.46, vocabulary was 7.43 , and performance was 7.96. This score then would be analyzed to get the description of their competence in transactional and interpersonal conversation. Accordingly, a good planning should be designed well to get better improvement in cycle 1 .
The video made by the students was completed after and during the third meeting of cycle I. The students were given a task to make a dialogue about giving suggestion in some situation. The topic was free or up to the students' preference. After the series of activities done the students were expected to improve their speaking ability in transactional and interpersonal conversation. The students' speaking results were evaluated and it was constructed into a result table. Table 3 shows the summary of the students' speaking result within Cycle I.

Table 3. The Summary of Speaking Achievement 1

\begin{tabular}{ccc}
\hline Category & $\begin{array}{c}\text { Average points earned } \\
(\mathbf{1 - 1 2})\end{array}$ & Percentage \\
\hline Pronunciation & 7.21 & $60 \%$ \\
Fluency & 7.88 & $66 \%$ \\
Comprehensibility & 8.49 & $71 \%$ \\
Vocabulary & 8.01 & $68 \%$ \\
Performance & 9.25 & $77 \%$ \\
Total / Average & 40.93 & 68 \\
\hline
\end{tabular}

Based on the Table 3, it was found that the average score in the Cycle I was 68. The students who achieved grade B were 17 (77\%) while $\mathrm{C}$ was 5 students $(23 \%)$. No one got grade $\mathrm{A}$ or $\mathrm{D}$. The result of average score and percentage of pronunciation, fluency, comprehensibility, vocabulary, and performance was respectively 7.21 (60\%), 7.88 (66\%), $8.49(71 \%), 8.01(68 \%)$, and 9.25 $(77 \%)$. 
The reflection was constructed based on the process during the actions and observation was conducted in Cycle I. The reflection is presented below.

1. Students' autonomy increasingly improved by implementing video making.

2. The students could make good video although a video had bad quality sound due to the recording time and the recording media quality.

3. The students were practising speaking English not only in the classroom but also outside the class and even after school time.

4. The highest score was performance category. It indicated that they had good confidence in speaking English when they performed in video.

5. Based on the result of students' speaking, it was found that they were still poor in pronunciation. For example when one of students said 'now', she said /no/ instead of /nau/.

6. Some students did not get involved during the discussion or consultation. It could be found in the observation sheet that did not all students answer the teachers' questions during the consultation in meeting 2 .

7. They could record and edit the video without the teacher's assistance. It was proven when some students directly submitted the finished video in the meeting 4 .

8. Before conducting the research, video uploading had been expected to make the students eager to study and happy in learning. In fact, it made the students felt burdensome and bored due to time consuming and bad internet connection.

9. It was found some ungrammatical texts and misspelling words in the video e.g. the word'actris', 'Udin meet meitia', 'it can useful for you', et cetera.

After analyzing the reflection in Cycle I, the further cycle was designed to overcome the weaknesses and develop the strengths found in the first Cycle.

Cycle II consisted of three meetings. In the first meeting, the students were taught the materials and asked to make a new dialogue about Giving Assessment, Criticizing, Predicting, Speculating expressions. In second meeting, they revised the dialogue they had made. While the 
third meeting was used for watching showed the students' speaking result the videos they had produced. Table 4 in Cycle II.

Table 4. The Summary of Speaking Result II

\begin{tabular}{ccc}
\hline Category & $\begin{array}{c}\text { Average points earned } \\
(\mathbf{1 - 1 2})\end{array}$ & Percentage \\
\hline Pronunciation & 7.75 & $65 \%$ \\
Fluency & 8.20 & $68 \%$ \\
Comprehensibili & 9.13 & $76 \%$ \\
ty & 8.84 & $74 \%$ \\
Vocabulary & 9.82 & $82 \%$ \\
Performance & 43.73 & 73 \\
Total / Average & & \\
\hline
\end{tabular}

Based on the students' speaking result as written in Table 4, it was found that the score of the students in the second video was 73 . This number was higher if compared with the average score in Cycle I. It was a good indication that the students' speaking ability was improved. The students' grade in this class was also increased. There were 3 students got grade A, while the rests (18 students) achieved grade B.

In the detail description, it was found that the average score and percentage of pronunciation was 7.75 $(65 \%)$, fluency was $8.20 \quad(68 \%)$, comprehensibility was 9.13 (76\%), vocabulary was $8.84(74 \%)$, and performance was $9.82(82 \%)$.

Before using video making, the students seldom practiced speaking in the classroom. Some English assignments given to them mostly focused on written forms instead of speaking activities. However, after the implementation of video making, the students could practise not only at school time, but also when they were out of school. Moreover, the students were able to create a video in satisfying level as the last product of learning. To understand more, the observation result about the students' autonomy was described in Figure 1. 


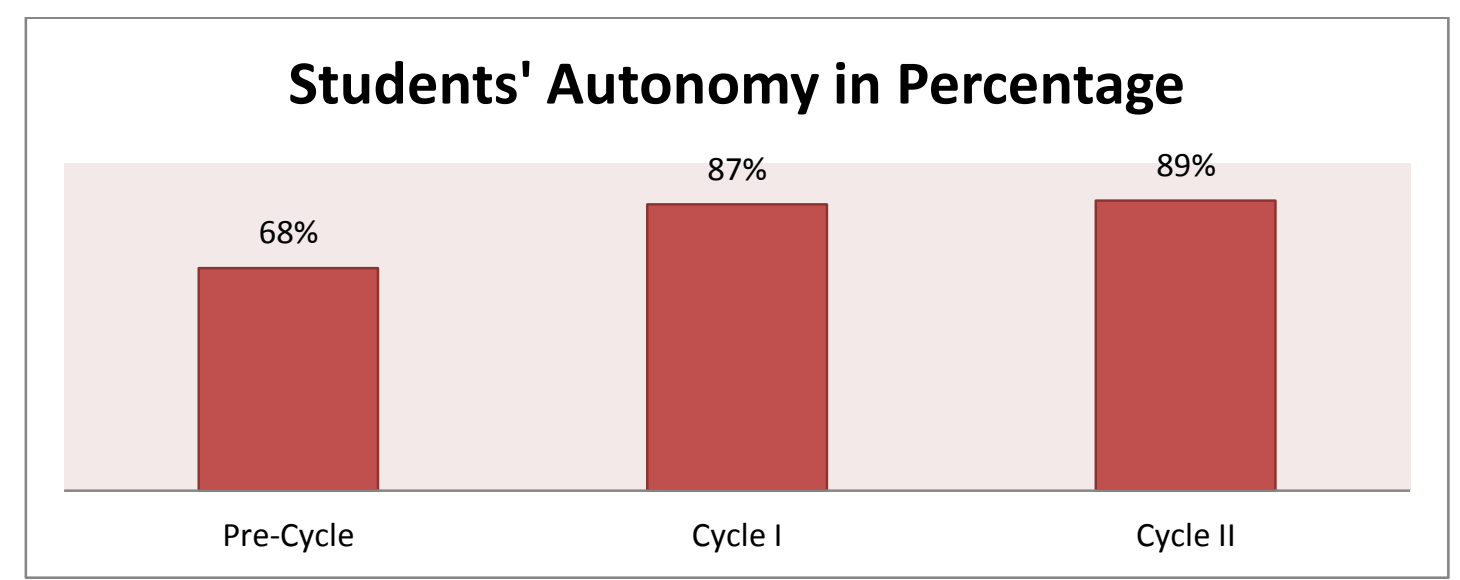

Figure 1. The result of Research Observation in Autonomy Based on the Questionnaire

Table 5. The Descriptions of the Percentage

\begin{tabular}{cc}
\hline Percentage & $\begin{array}{c}\text { Level of } \\
\text { achievement }\end{array}$ \\
\hline $91-100 \%$ & Excellent \\
$75-90 \%$ & Good \\
$51-74 \%$ & Fair \\
$<50 \%$ & Poor \\
\hline
\end{tabular}

Based on the chart written in Figure 1, it shows that the students' autonomy in pre-cycle was $68 \%$. After the students were treated in the first cycle, the level of achievement increased sharply in $87 \%$ while the percentage of second cycle was increased to $89 \%$. Therefore, the students' autonomy in the cycle I improved from the level fair into good. It could also be seen that the students' level in the second cycle was close to the level of excellent. In other words, the students were better in taking their learning independently and more responsible for the process of it.

After discussing the autonomy, the students' ability in speaking of transactional and interpersonal conversation became another focus. It was expected that the students could improve their speaking skill after using video making. Figure 2 showed clearly the development of students' speaking competence from pre-cycle to the end of cycle II. 


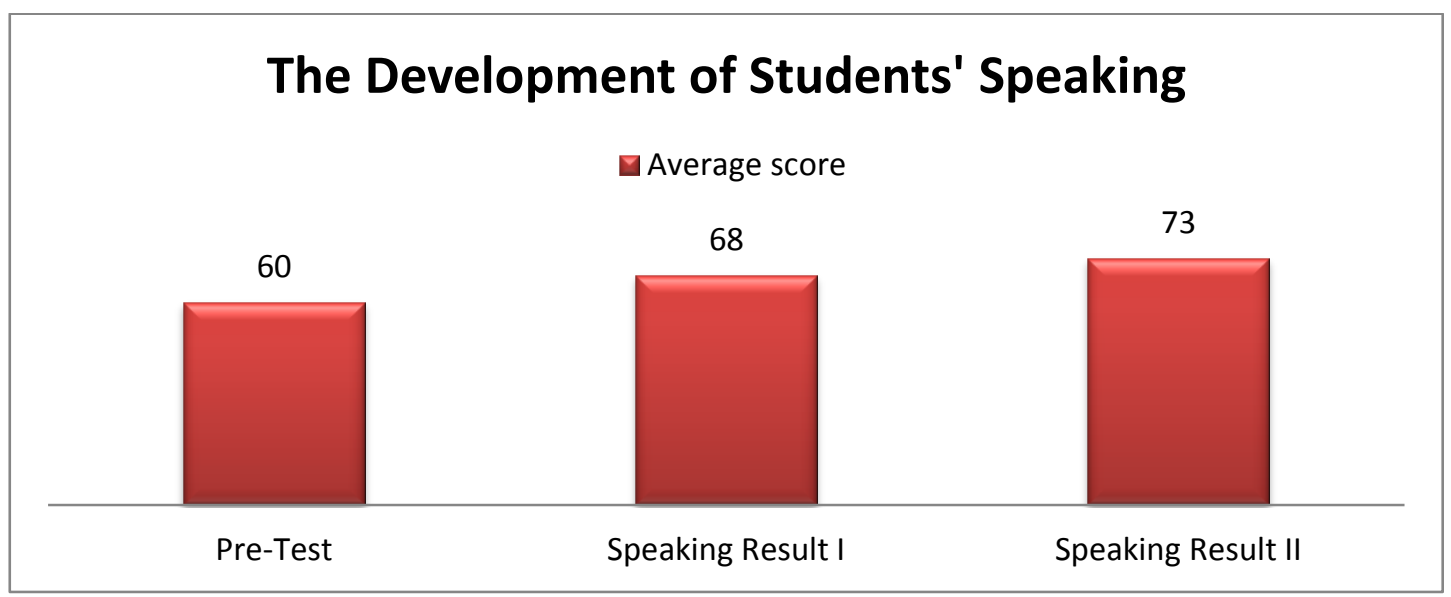

Figure 2. The Development of Students' Speaking in Transactional and Interpersonal Conversations

Figure 2 shows that the students' speaking ability improved gradually from the pre-cycle to the second cycle. The average score of pre-cycle was 60 and the students who got B was 59\% from the total number while the rests achieved $\mathrm{C}$. The average score of speaking result I was 68 while 17 students (77\%) achieved grade B and 5 others $(23 \%)$ got grade C. In the speaking result II, the average score was increased in to 73 while 3 students (14\%) got $\mathrm{A}$ and 19 others (86\%) achieved B.

To make it clearer, the score could be broken down into some categories. They described the students' speaking skill into deeper explanation. Each category described different achievement but overall the students' speaking skill in transactional and interpersonal conversations were improved. Figure 3 shows the improvement of students' speaking result during the treatments in each category. 


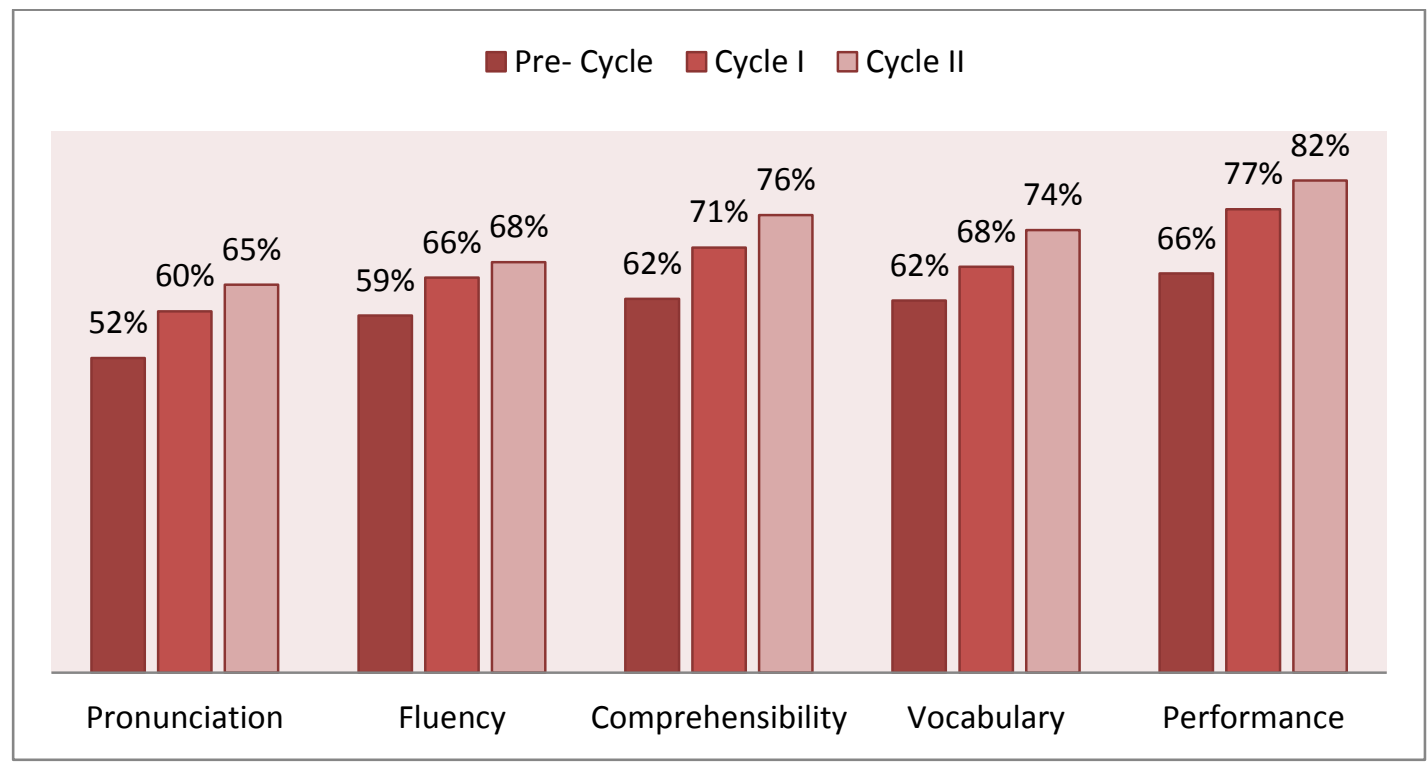

Figure 3. The Progress of Students' Speaking in Transactional and Interpersonal Conversation in Each Category

Based on the data written in Figure 3, it can be seen that the students' speaking ability in each category generally were improved. The average of pronunciation in pre-cycle was $52 \%$; Cycle I was 60\%, Cycle II was $65 \%$.The fluency average in pre-cycle was 59\%, Cycle I was 66\%, and Cycle II was $68 \%$. The comprehensibility average score in pre-cycle was $62 \%$, Cycle I was $71 \%$, and Cycle II was $76 \%$. The vocabulary average score in pre-cycle was $62 \%$, Cycle I was $68 \%$, and Cycle II was 74. At last, the average score of performance in precycle was $66 \%$, Cycle I was $77 \%$, and Cycle II was $82 \%$.

\section{CONCLUSION}

The study deals with the use of video making project to improve the students' autonomy and speaking ability in transactional and interpersonal conversations. After finding and discussing the results, the conclusions are as follows.

Firstly, the problems faced by the teacher and students of SMA 1 Limbangan in implementing Video Making were the difficulty of (1) uploading video on YouTube, (2) handling the project at the same time doing many tasks from other subject, (3) taking too much time when uploading on YouTube, and (4) using 
good a recording media and choosing suitable time to record the video.

Secondly, video making was implemented through action research. It consisted of pre-cycle, Cycle I, and Cycle II. In Cycle I, the students were asked to make and revise a dialogue, shoot the raw videos, and edit them into a good video dealing with transactional and interpersonal conversation. In the last step, the students needed to upload the video on YouTube. Cycle II was done the same as what had been done in Cycle I. However, the video uploading was skipped because of the matter of time and efficiency.

Thirdly, video making applied in the classroom could successfully help the students to improve their learning autonomy and ability in transactional and interpersonal conversations. It was shown in the level of students' autonomy that was increased sharply and the students' average score that was also improved gradually.

\section{REFERENCES}

Adamson, John \&Sert, Nehir. (2012).
English as Foreign Language.

International Journal of

Global Education - 2012,

volume 1 issue 2. Available

online on

http://www.ijge.net/ojs/index.

php/ijge/article/view/69.

Accessed on July $19^{\text {th }}, 2013$.

Brown, H. Douglas. (2004). Language Assessment: Principles and Classroom Practices. New York: Longman

Brown, J D. (1988). Understanding Researchin Second Language Learning. Cambridge: Cup.

Burns, Anne. (2010). Doing Action Research in English Language Teaching: a Guide for Practitioners. New York and London: Routledge.

Celce-Murcia M, Dornyei Z, Thurrell S. (1995). Communicative Competence: A Pedagogical Motivated Model with Content Specifications. Issues in Applied Linguistics, 6 ( 2 ), $5-35$.
Autonomy in Learning 
Cohen et al. (2007). Research Method

in Education. London and

New York: Routledge.

Eggins and Slade ( 1997 ). Analysing

Casual Conversation in Advances in Spoken

Discourse Analysis. Malcolm

Coulthard( ed. ). London :Routledge.

Fotos, Sandra \& Browne, Charles M. (2004). New Perspective on CALL for Second Language Classroom. London: Lawrence Erlbaum Associates, Publishers.

Harmer, Jeremy. (1998). How to Teach English(an Introduction to the practice of English Language Teaching). London: Longman.

Holec, H. (1981). Autonomy and Foreign Language Learning. Oxford: Pergamon Press.

KOMPAS.com. (2012). Jumlah Pengguna Facebook Indonesia Disusul India. Accessed on February 1,
2012. Available online on http://tekno.kompas.com/read /2012/02/01/09153884/Jumla h.Pengguna.Facebook.Indone sia.Disusul.India.

Little, D. (1991).Learner Autonomy1: Definitions, Issues and Problems. Dublin: Authentic.

Masats, Dooly \& Costa. (2009). Mini Guide: Video Production and Language Learning. Divis Division for Learning. Available online on http://www.divisproject.eu/att achments/143_Divis-MiniGuide-English.pdf. Accessed on December 26, 2012.

Mergendoller, John R. \& Thomas, John W. (2000). Managing Project Based Learning: Principles from the Field. Buck Institute for Education Journal. Available on www.bie.org. accessed on December 12, 2013.

Ministry of National Education. (2006). English content standard number 22 year 
2006). Jakarta: Ministry of National Education.

Richards, J. (1990). The Language Teaching Matrix. Cambridge: University Press.

Sentlowits, Shari. (2009). Engaging Students in Video Production and Movie Making in the Classroom (presented on December 9, 2009 at $1 \mathrm{pm}$ to 4pm). PowerPoint presentation of Sony Corporation. Available online on www.techlearning.com.

Accessed on November 20, 2012.

Tatarko, Michal. (2011). Searching for the Parallels between Motivation and Autonomous Learning in ELT. Prešov University Document. www. pulib.sk. Accessed on July $19^{\text {th }}, 2013$.

Wachob, Philips. (2004). Methods and materials for motivationand learner autonomy. The American University in Cairo
Journal. Available online on www.nus.edu.sg. Accessed on March 14 ${ }^{\text {th }}, 2013$.

Wachob, Philips. (2011). Using Videos of Students in The Classroom to Enhance Learner Autonomy. Teaching English with Technology Journal, 11 (2), 18-28. Available online on www.tewtjournal.org.

Accessed on December 3, 2012.

Wlodkowski Raymond J. (2008). Enhancing Adult Motivation to Learn: A Comprehensive Guide for Teaching All Adults. $\quad\left(3^{\text {rd }}\right.$ ed. $) \quad$ San Francisco: Jossey-Bass.

York, James. (2011). Reasons for Using YouTube in the Language Classroom Including Practical Usage Examples. The JALT Call Journal. (ISSN 1832-4215) Vol. 7, no. 2 Pages 207-215. Available on journal.jaltcall.org. Accessed on November 25, 2012. 
YouTube Statistic. (2012). Press ress_statistics. Accessed on Statistic. Available online on December $26, \quad 2012$. phttp://www.youtube.com/t/p 


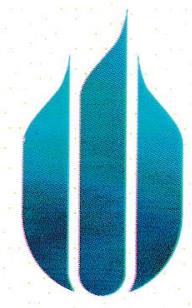

U N I VER S I TAS

MERCU BUANA

Y O G Y A K A R T A

ENGLISH EDUCATION STUDY PROGRAM

Faculty of Teachers Training and Education

Mercu Buana University of Yogyakarta

J. Wates Km. 10 Yogyakarta 55753 | jurnal.umby@gmail.com

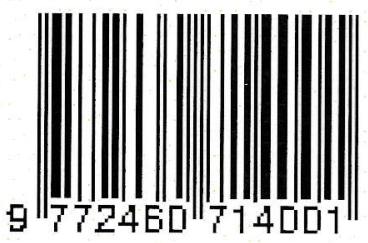

